\title{
Pengaruh Takaran Kombinasi Pupuk NPK dan Pupuk Organik Alami Diperkaya Mikroba Fungsional terhadap Pertumbuhan dan Hasil Jagung (Zea mays L.)
}

\section{The Effect of Different Combination of NPK Fertilizers and Organic Fertilizers Enriched with Functional Microbes on the Growth and Yield of Maize (Zea mays L.)}

\author{
Irma Erselia ${ }^{1)}$, Dyah Weny Respatie ${ }^{\left.2^{*}\right)}$, Rohlan Rogomulyo ${ }^{2)}$ \\ 1) Program Studi Agronomi, Fakultas Pertanian, Universitas Gadjah Mada \\ ${ }^{2)}$ Departemen Budidaya Pertanian, Fakultas Pertanian, Universitas Gadjah Mada \\ ${ }^{*}$ Penulis untuk korespodensi E-mail: wenyrespatie@ugm.ac.id
}

\begin{abstract}
This research was conducted on March to June 2015 at experimental field of Faculty of Agriculture, Universitas Gadjah Mada, located at Banguntapan, Bantul, Yogyakarta. The objectives of this research are to determine the combination of NPK fertilizers and enriched organic fertilizer (EOF) doses that give optimal growth and yield of maize, and to understand the effectiveness of EOF for promoting the growth and yield of maize. The research was arranged in randomized complete block design with three replications for each treatment. The treatments were combination of NPK fertilizers (NPK compound + urea) and EOF doses in 7 levels, i.e.: without fertilizer (P0), 300 $\mathrm{kg} / \mathrm{ha} N P K+250 \mathrm{~kg} / \mathrm{ha}$ urea (P1), 2 ton/ha EOF (P2), $300 \mathrm{~kg} / \mathrm{ha} N P K+250 \mathrm{~kg} / \mathrm{ha}$ urea + 2 ton/ha EOF (P3), $225 \mathrm{~kg} / \mathrm{ha} N P K+187,5 \mathrm{~kg} / \mathrm{ha}$ urea + 2 ton/ha EOF (P4), 150 $\mathrm{kg} / \mathrm{ha} N P K+125 \mathrm{~kg} / \mathrm{ha}$ urea +2 ton/ha EOF (P5) and $75 \mathrm{~kg} / \mathrm{ha} N P K+62,5 \mathrm{~kg} / \mathrm{ha}$ urea +2 ton/ha EOF (P6). The data were analyzed by ANOVA $(P<0,05)$ and continued using DMRT at probability level of $5 \%$ if significantly different. The result showed that optimal growth and yield of maize (6,12 ton/ha) were attained by combination of 300 $\mathrm{kg} / \mathrm{ha} N P K+250 \mathrm{~kg} / \mathrm{ha}$ urea dose $(P 1)$. The growth and yield of maize $(6,09 \mathrm{ton} / \mathrm{ha})$ at combination of $225 \mathrm{~kg} / \mathrm{ha} N P K+187,5 \mathrm{~kg} / \mathrm{ha}$ urea +2 ton/ha EOF dose (P4) were as high as standard NPK (P1). Combination of $3 / 4$ NPK standard +2 ton/ha EOF (P4) promoted growth and yield of maize effectively with RAE value up to $100 \%$.
\end{abstract}

Keywords: dose of NPK fertilizers, enriched organic fertilizer, growth and yield, maize, $R A E$

\section{INTISARI}

Penelitian ini dilaksanakan pada bulan Maret sampai dengan Juni 2015 di Kebun Percobaan Fakultas Pertanian Universitas Gadjah Mada, di Banguntapan, Bantul, Yogyakarta. Penelitian ini bertujuan untuk menentukan takaran kombinasi pupuk NPK dan pupuk organik alami diperkaya mikroba fungsional (POD) yang memberikan pertumbuhan dan hasil jagung optimal, dan mengetahui efektivitas POD dalam meningkatkan pertumbuhan dan hasil jagung. Perlakuan disusun dalam rancangan acak kelompok lengkap faktor tunggal dengan 3 blok sebagai ulangan. Faktor yang 
diuji berupa takaran kombinasi pupuk NPK (NPK majemuk + urea) dan POD yang terdiri atas 7 aras yaitu tanpa pupuk (P0), $300 \mathrm{~kg} / \mathrm{ha} \mathrm{NPK}+250 \mathrm{~kg} / \mathrm{ha}$ urea (P1), 2 ton/ha POD (P2), $300 \mathrm{~kg} / \mathrm{ha} \mathrm{NPK}+250 \mathrm{~kg} / \mathrm{ha}$ urea + 2 ton/ha POD (P3), $225 \mathrm{~kg} / \mathrm{ha}$ NPK + 187,5 kg/ha urea + 2 ton/ha POD (P4), $150 \mathrm{~kg} / \mathrm{ha}$ NPK + $125 \mathrm{~kg} / \mathrm{ha}$ urea +2 ton/ha POD (P5) dan $75 \mathrm{~kg} / \mathrm{ha}$ NPK + 62,5 kg/ha urea + 2 ton/ha POD (P6). Data pengamatan dianalisis menggunakan ANOVA dengan taraf signifikasi $5 \%$ dan apabila terdapat beda nyata dilakukan uji lanjut Duncan Multiple Range Test dengan taraf signifikasi yang sama. Hasil penelitian menunjukkan pertumbuhan dan hasil pipilan kering biji jagung optimal $(6,12$ ton/ha) dicapai oleh perlakuan $300 \mathrm{~kg} / \mathrm{ha}$ NPK +250 $\mathrm{kg} / \mathrm{ha}$ urea (P1). Takaran kombinasi pupuk $225 \mathrm{~kg} / \mathrm{ha} \mathrm{NPK}+187,5 \mathrm{~kg} / \mathrm{ha}$ urea +2 ton/ha POD (P4) memberikan pertumbuhan dan hasil jagung $(6,09$ ton/ha) yang sama baiknya dengan takaran NPK standar (P1). POD sebanyak 2 ton/ha yang dikombinasikan dengan $3 / 4$ NPK standar (P4) efektif meningkatkan pertumbuhan dan hasil jagung dengan nilai RAE mendekati $100 \%$.

Kata kunci: jagung, pertumbuhan dan hasil, pupuk organik, RAE, takaran pupuk NPK

\section{PENDAHULUAN}

Jagung merupakan tanaman pangan penting di Indonesia. Pada tahun 2014 sektor pertanian (di luar perikanan dan kehutanan) berkontribusi 880,39 triliun rupiah atau 10,28\% dari Produk Domestik Bruto (PDB) (BPS, 2016a). Pada tahun 2015 produksi jagung nasional sebesar 19.612.435 ton (BPS, 2016c) sementara sasaran produksi tahun 2015 sebesar 20.313 .731 ton (Pusdatin Kementan, 2015) atau mengalami defisit 701.296 ton. Untuk mengatasi hal itu pemerintah melakukan impor. Jagung merupakan komoditi terbesar ke-3 yang diimpor setelah gandum dan kedelai (Kementan, 2015). Oleh karena itu agar tercipta kedaulatan pangan dan pakan lokal maka produksi jagung nasional perlu ditingkatkan.

Dalam upaya peningkatan produksi pertanian penggunaan pupuk kimia sudah menjadi kebutuhan, khususnya dalam budidaya jagung hibrida. Jagung hibrida telah mengalami proses peningkatan kualitas genetik termasuk potensial hasil yang tinggi, sehingga lebih membutuhkan banyak pemupukan NPK untuk hasil yang optimal. Peningkatan produksi yang signifikan membuat petani selalu menggunakan pupuk kimia, akan tetapi dalam jangka panjang hal tersebut dapat mengancam keberlanjutan kegiatan pertanian karena dapat menyebabkan dampak serius bagi lingkungan (Savci, 2012a). Selain itu seiring meningkatnya kebutuhan, harga pupuk kimia khususnya NPK menjadi semakin mahal. Harga eceran tertinggi (HET) pupuk bersubsidi yang ditetapkan pemerintah yaitu Rp. 1.800 per kg untuk pupuk urea dan Rp. 2.300 per kg untuk pupuk NPK (Permentan No. 60, 2015), sedangkan HET pupuk non subsidi di kalangan pengecer bisa mencapai Rp. 13.000 per kg. 
Untuk mengurangi biaya pupuk kimia, petani biasa menambahkan pupuk organik alami seperti kompos dan pupuk kandang. Pupuk organik alami tersebut biasanya diaplikasikan dalam jumlah besar yaitu rata-rata 10 ton/ha (Kresnatita et al., 2013) bahkan lebih untuk mendapatkan hasil yang signifikan. Akan tetapi pupuk organik alami dalam jumlah banyak dan dalam waktu yang bersamaan biasanya relatif kurang tersedia. Oleh karena itu teknologi pemupukan dalam dunia pertanian terus dikembangkan salah satunya dengan penggunaan pupuk organik yang diperkaya dengan mikroba fungsional. Pupuk tersebut dapat dijadikan alternatif karena takaran yang dibutuhkan jauh lebih sedikit yaitu hanya 2 ton/ha, sehingga biaya pupuk bisa dikurangi karena HET pupuk organik yang ditetapkan pemerintah cukup terjangkau yaitu Rp. 500 per kg (Permentan No. 60, 2015). Selain itu, pupuk organik tersebut lebih unggul karena telah diperkaya dengan mikroba fungsional seperti Rhizobium sp., Trichoderma sp. dan Bacillus sp. dibanding pupuk organik alami pada umumnya. Penggunaan pupuk organik yang diperkaya dengan mikroba fungsional diharapkan dapat dijadikan alternatif pemupukan karena harganya lebih murah sehingga penggunaan pupuk kimia dapat dikurangi dan dampak negatif penggunaan pupuk kimia bagi lingkungan dapat diminimalisasi.

Oleh karena itu penelitian ini dilakukan dengan tujuan untuk menentukan takaran kombinasi pupuk NPK dan pupuk organik alami diperkaya mikroba fungsional yang memberikan pertumbuhan dan hasil jagung (Zea mays L.) optimal dan mengetahui efektivitas pupuk organik alami diperkaya mikroba fungsional dalam meningkatkan pertumbuhan dan hasil jagung (Zea mays L.).

\section{BAHAN DAN METODE}

Penelitian ini dilaksanakan pada bulan Maret sampai dengan Juni 2015 di Kebun Tri Dharma Fakultas Pertanian, Universitas Gadjah Mada, di Banguntapan, Bantul, Yogyakarta. Alat yang digunakan dalam penelitian ini yaitu alat tanam, alat tulis, oven, timbangan analitik, jangka sorong, leaf area meter, thermohygrometer dan lux meter. Bahan yang digunakan dalam penelitian ini berupa benih jagung varietas Pioneer 27, pupuk NPK majemuk (15:15:15), pupuk urea, pupuk organik alami diperkaya mikroba fungsional dan Furadan 3GR.

Perlakuan disusun dalam rancangan acak kelompok lengkap (RAKL) faktor tunggal dengan 3 blok sebagai ulangan. Faktor yang diuji berupa takaran kombinasi pupuk NPK (NPK majemuk + urea) dan pupuk organik diperkaya mikroba fungsional (POD) yang terdiri atas 7 aras yaitu P0 = tanpa pupuk (kontrol); P1 $=300 \mathrm{~kg} / \mathrm{ha} \mathrm{NPK} \mathrm{+}$ 
$250 \mathrm{~kg} / \mathrm{ha}$ urea (NPK standar); P2 = 2 ton/ha POD (organik standar); P3 = $300 \mathrm{~kg} / \mathrm{ha}$ NPK $+250 \mathrm{~kg} / \mathrm{ha}$ urea +2 ton/ha POD (NPK standar + organik standar); P4 = 225 $\mathrm{kg} / \mathrm{ha}$ NPK + 187,5 kg/ha urea + 2 ton/ha POD (3/4 NPK standar + organik standar); P5 = $150 \mathrm{~kg} / \mathrm{ha}$ NPK + $125 \mathrm{~kg} / \mathrm{ha}$ urea + 2 ton/ha POD ( $1 / 2$ NPK standar + organik standar); P6 = $75 \mathrm{~kg} / \mathrm{ha}$ NPK $+62,5 \mathrm{~kg} / \mathrm{ha}$ urea +2 ton/ha POD (1/4 NPK standar + organik standar). Takaran $300 \mathrm{~kg} / \mathrm{ha}$ NPK $+250 \mathrm{~kg} / \mathrm{ha}$ urea digunakan sebagai takaran NPK standar sesuai dengan penelitian terdahulu pada jagung varietas Pioneer (Kasno \& Rostaman, 2013). Data pengamatan yang diperoleh diuji secara statistik dengan analisis varians untuk rancangan acak kelompok lengkap (RAKL), dan apabila terdapat beda nyata dilanjutkan pembandingan antar perlakuan dengan uji Jarak Berganda Duncan (Duncan Multiple Range Test = DMRT) pada taraf signifikasi 5\%.

\section{HASIL DAN PEMBAHASAN}

Suhu udara selama penelitian teramati lebih tinggi dibanding kondisi idealnya. Menurut Gerpacio \& Pingali (2007), kisaran suhu $22^{\circ} \mathrm{C}-32^{\circ} \mathrm{C}$ umumnya merupakan ciri lingkungan tumbuh jagung di daerah tropis. Hasil jagung akan meningkat sampai suhu $29^{\circ} \mathrm{C}$ (Schlenker \& Roberts, 2009) dan mulai terjadi penurunan hasil pada ambang batas kritis suhu udara yaitu $32^{\circ} \mathrm{C}$ (Plessis, 2003). Apabila terpapar suhu udara di atas $32^{\circ} \mathrm{C}$ viabilitas polen akan menurun (Schoper et al., 1987) dan tingkat fertilisasi sangat berkurang (Dupuis and Dumas, 1990).

Tabel 1. Data pengamatan lingkungan penelitian

\begin{tabular}{ccccc}
\hline Bulan & $\begin{array}{c}\text { Intensitas } \\
\text { Cahaya (Fc) }\end{array}$ & Suhu Udara $\left({ }^{\circ} \mathrm{C}\right)$ & $\begin{array}{c}\text { Kelembapan Udara } \\
\text { Relatif }(\%)\end{array}$ & $\begin{array}{c}\text { Curah Hujan } \\
\text { Bulanan }(\mathrm{mm})\end{array}$ \\
\hline April & $8.599,11$ & 35,1 & 70,8 & 469 \\
Mei & $7.851,24$ & 34,2 & 67,2 & 293 \\
Juni & $7.701,66$ & 31,1 & 63,0 & 59 \\
\hline
\end{tabular}

Sumber: BMKG dan Data Pengamatan (2015).

Analisis Kandungan hara tanah sebelum dilakukan penelitian dapat dikategorikan ke dalam tanah yang miskin hara. Hal ini dapat dilihat dari kondisi tanah yang masam dengan kandungan $\mathrm{C}$-Organik, $\mathrm{N}$-total dan $\mathrm{K}_{2} \mathrm{O}$ potensial yang sangat rendah serta $\mathrm{P}_{2} \mathrm{O}_{5}$ yang sangat tinggi namun tidak tersedia bagi tanaman. The et al. (2006) mengemukakan bahwa hasil biji jagung berkurang pada tanah masam. Umumnya ketersediaan unsur mikro seperti besi (Fe), mangan ( $\mathrm{Mn})$, boron (B), tembaga $(\mathrm{Cu})$ dan seng $(\mathrm{Zn})$ meningkat pada tanah yang cukup masam (Heggenstaller, 2016). 
Irma Erselia et al., / Vegetalika. 2017. 6(4): 28-40

Tabel2. Kandungan hara tanah sebelum penelitian

\begin{tabular}{ccccc}
\hline No. & Parameter & Nilai & Satuan & Harkat \\
\hline 1. & $\mathrm{pH} \mathrm{H} \mathrm{H}_{2} \mathrm{O}$ & 4,95 & & $4,5-5,5$ masam \\
2. & $\mathrm{C}-$ Organik & 0,51 & $\%$ & $<1$ sangat rendah \\
3. & N Total & 0,05 & $\%$ & $<0,1$ sangat rendah \\
4. & $\mathrm{P}_{2} \mathrm{O}_{5}$ Potensial & 218 & $\mathrm{mg} / 100 \mathrm{~g}$ & $>60$ sangat tinggi \\
5. & $\mathrm{~K}_{2} \mathrm{O}$ Potensial & 6 & $\mathrm{mg} / 100 \mathrm{~g}$ & $<10$ sangat rendah \\
\hline
\end{tabular}

Sumber: Balai Pengkajian Teknologi Pertanian Yogyakarta, 2015

Hasil analisis juga menunjukkan kandungan $\mathrm{P}_{2} \mathrm{O}_{5}$ potensial yang tinggi tersebut menjadi tidak tersedia bagi tanaman karena tanah mempunyai $\mathrm{pH}$ yang masam. Menurut Heggenstaller (2016) tanah dengan pH di bawah 6,5 menyebabkan unsur fospor (P) menjadi tidak tersedia karena berikatan dengan Fe dan Al membentuk senyawa yang tidak larut.

Hasil analisis tersebut menunjukkan bahwa kandungan unsur makro yaitu $\mathrm{N}$ total, $\mathrm{P}_{2} \mathrm{O}_{5}$ total dan $\mathrm{K}_{2} \mathrm{O}$ total tidak memenuhi standar mutu yang telah ditetapkan sehingga pupuk organik ini tidak ideal untuk digunakan sebagai pupuk jagung hibrida yang mana kebutuhan hara makro-nya sangat tinggi.

Tabel 3. Kandungan hara pupuk organik

\begin{tabular}{ccccc}
\hline No. & Parameter $^{2}$ & Hasil & Satuan & Standar Mutu \\
\hline 1. & C-Organik $^{\mathrm{a}}$ & 26,4 & $\%$ & Min. 15 \\
2. & ${\mathrm{C} / \mathrm{N} \mathrm{rasio}^{\mathrm{a}}}_{3 .}$ & 22,4 & - & $15-25$ \\
3. & $\mathrm{pH} \mathrm{H}_{2} \mathrm{O}^{\mathrm{a}}$ & 7,05 & - & $4-9$ \\
4. & $\mathrm{~N} \mathrm{Total}^{\mathrm{a}}$ & 1,18 & $\%$ & Min. 4 \\
5. & $\mathrm{P}_{2} \mathrm{O}_{5}$ total $^{\mathrm{a}}$ & 1,32 & $\%$ & Min. 4 \\
6. & $\mathrm{~K}_{2} \mathrm{O}$ total & & \\
7. & Kadar Air $^{\mathrm{a}}$ & 1,73 & $\%$ & Min. 4 \\
8. & Rhizobium sp. $^{\mathrm{b}}$ & 15,9 & $\%$ & \\
9. & Trichoderma sp. $^{\mathrm{b}}$ & $9,5 \times 10^{\prime}$ & $\mathrm{Cfu} / \mathrm{g}$ & \\
10. & Bacillus sp. $^{\mathrm{b}}$ & $1,3 \times 10^{6}$ & $\mathrm{Cfu} / \mathrm{g}$ & \\
\hline
\end{tabular}

Sumber: $\quad a=$ Balai Pengkajian Teknologi Pertanian Yogyakarta (2015)

$\mathrm{b}=$ Balai Pengkajian Teknologi Pertanian Jawa Timur (2013)

Berdasarkan Tabel 4.4. $\mathrm{pH}$ tanah meningkat menjadi berharkat agak masam. Kandungan C-organik dan $\mathrm{N}$-total sangat rendah pada semua perlakuan, atau sama dengan analisis tanah sebelum penelitian (Tabel 2). Kandungan $\mathrm{P}_{2} \mathrm{O}_{5}$ tersedia juga tetap sangat tinggi pada semua perlakuan. Pemupukan dengan pupuk organik mampu meningkatkan ketersediaan unsur $\mathrm{K}$ dalam tanah menjadi sangat tinggi. Sedangkan perlakuan tanpa pupuk mempunyai kandungan $\mathrm{K}$ tersedia yang sedang. 
Tabel 4. Kandungan hara tanah setelah penelitian

\begin{tabular}{|c|c|c|c|c|c|c|c|c|c|}
\hline No. & Parameter & P0 & P1 & $\mathrm{P} 2$ & P3 & P4 & P5 & P6 & Keterangan $^{a}$ \\
\hline 1. & $\mathrm{pH} \mathrm{H} \mathrm{H}_{2} \mathrm{O}$ & 6,01 & 6,13 & 6,14 & 6,01 & 5,98 & 6,06 & 5,98 & $\begin{array}{c}5,5-6,5 \\
\text { agak masam }\end{array}$ \\
\hline 2. & $\begin{array}{c}\text { C-Organik } \\
(\%)\end{array}$ & 0,93 & 0,67 & 0,54 & 0,62 & 0,69 & 0,73 & 0,48 & $\begin{array}{l}\quad<1 \\
\text { sangat rendah }\end{array}$ \\
\hline 3. & N-Total $(\%)$ & 0,06 & 0,05 & 0,05 & 0,05 & 0,05 & 0,05 & 0,06 & $\begin{array}{l}<0,1 \\
\text { sangat rendah }\end{array}$ \\
\hline 4. & $\begin{array}{c}\mathrm{P}_{2} \mathrm{O}_{5} \text { tersedia } \\
(\mathrm{ppm})\end{array}$ & 95 & 100 & 95 & 103 & 118 & 118 & 106 & $\begin{array}{c}>20 \\
\text { sangat tinggi }\end{array}$ \\
\hline 5. & $\begin{array}{l}\mathrm{K} \text { tersedia } \\
\text { (me/100g) }\end{array}$ & 0,36 & 0,59 & 0,66 & 0,59 & 0,63 & 0,63 & 0,62 & $\begin{array}{c}0,4-0,5 \text { sedang } \\
0,6-1,0 \text { tinggi }\end{array}$ \\
\hline
\end{tabular}

Sumber: Balai Pengkajian Teknologi Pertanian Yogyakarta (2015); ${ }^{a}$ Balai Penelitian Tanah (2009)

Pada fase reproduktif (umur $13 \mathrm{mst}$ ) pemupukan $1 / 4$ NPK standar + organik standar menyebabkan pertumbuhan rambut akar yang baik namun tidak dengan pertumbuhan tajuknya. Tanaman yang dipupuk dengan $1 / 4$ NPK standar + organik standar mempunyai tinggi tanaman, jumlah daun dan luas daun yang secara nyata lebih rendah (Tabel 5). Hal ini diduga disebabkan oleh rendahnya takaran NPK yang diberikan sehingga asimilat yang terbentuk lebih banyak ditranslokasikan untuk pertumbuhan rambut akar daripada untuk pertumbuhan tajuk. Hasil ini dibuktikan oleh parameter rasio akar dengan tajuk pada perlakuan pemupukan 1/4 NPK standar + organik standar yang secara nyata lebih tinggi daripada perlakuan kombinasi pemupukan lainnya (Tabel 8). Tanaman merespons pembatasan nitrogen di dalam tanah dengan meningkatkan jumlah translokasi biomassa ke bagian akar (Bonifas et al., 2005).

Tabel 5. Tinggi tanaman, diameter bantang, jumlah daun dan luas daun jagung pada berbagai takaran kombinasi pupuk umur $13 \mathrm{mst}$

\begin{tabular}{lcccc}
\hline \multicolumn{1}{c}{ Kombinasi Pupuk } & $\begin{array}{c}\text { Tinggi } \\
\text { Tanaman } \\
(\mathrm{cm})\end{array}$ & $\begin{array}{c}\text { Diameter } \\
\text { Batang } \\
(\mathrm{mm})\end{array}$ & $\begin{array}{c}\text { Jumlah } \\
\text { Daun }\end{array}$ & $\begin{array}{c}\text { Luas Daun } \\
\left(\mathrm{cm}^{2}\right)\end{array}$ \\
\hline Tanpa Pupuk & $140,65 \mathrm{c}$ & $14,05 \mathrm{~b}$ & $6,93 \mathrm{c}$ & $2.156,70 \mathrm{c}$ \\
Organik Standar & $160,25 \mathrm{c}$ & $14,87 \mathrm{~b}$ & $9,68 \mathrm{~b}$ & $2.264,15 \mathrm{c}$ \\
NPK Standar & $242,14 \mathrm{ab}$ & $23,96 \mathrm{a}$ & $13,40 \mathrm{a}$ & $3.817,99 \mathrm{a}$ \\
NPK Standar + Organik Standar & $238,15 \mathrm{ab}$ & $22,79 \mathrm{a}$ & $10,71 \mathrm{ab}$ & $3.727,69 \mathrm{a}$ \\
3/4 NPK Standar + Organik Standar & $258,03 \mathrm{a}$ & $23,20 \mathrm{a}$ & $12,08 \mathrm{ab}$ & $3.267,05 \mathrm{ab}$ \\
1/2 NPK Standar + Organik Standar & $246,04 \mathrm{ab}$ & $22,40 \mathrm{a}$ & $10,18 \mathrm{ab}$ & $3.046,58 \mathrm{~b}$ \\
1/4 NPK Standar + Organik Standar & $225,04 \mathrm{~b}$ & $20,90 \mathrm{a}$ & $9,22 \mathrm{~b}$ & $3.053,84 \mathrm{~b}$ \\
\hline CV (\%) & 4,38 & 7,87 & 7,28 & 10,45 \\
\hline
\end{tabular}

Keterangan: Nilai yang diikuti huruf sama dalam kolom yang sama tidak berbeda signifikan pada Uji Jarak Berganda Duncan $\alpha=5 \%$.

Pemupukan $1 / 4$ NPK standar + organik standar dan $1 / 2$ NPK standar + organik standar masih mampu menyediakan nutrisi untuk pertumbuhan vegetatif tanaman, tetapi seiring memasuki fase reproduktif kebutuhan unsur hara meningkat. Setelah inisiasi biji terjadi, daerah pemanfaatan hasil fotosintesis dialihkan untuk 
perkembangan biji dan kemampuan penyerapan hasil fotosintesis menjadi sangat kuat sehingga membatasi pertumbuhan daun, batang dan akar. Rajcan \& Tollenaar (1999a) menyebutkan bahwa periode kritis terhadap suplai nitrogen terjadi saat pertumbuhan reproduktif, ketika pembagian karbohidrat dari yang semula untuk aktivitas pertumbuhan akar digeser untuk mendukung pertumbuhan dan perkembangan tongkol.

Tabel 6. Volume akar, panjang akar total, luas permukaan akar dan bobot segar akar jagung pada berbagai takaran kombinasi pupuk umur $13 \mathrm{mst}$

\begin{tabular}{lcccc}
\hline \multicolumn{1}{c}{ Kombinasi Pupuk } & $\begin{array}{c}\text { Volume } \\
\text { Akar } \\
(\mathrm{ml})\end{array}$ & $\begin{array}{c}\text { Panjang } \\
\text { Akar Total } \\
(\mathrm{cm})\end{array}$ & $\begin{array}{c}\text { Luas } \\
\text { Permukaan } \\
\text { Akar }\left(\mathrm{cm}^{2}\right)\end{array}$ & $\begin{array}{c}\text { Bogar } \\
(\mathrm{g})\end{array}$ \\
\hline Tanpar Pupuk & $8,85 \mathrm{~d}$ & $1726,10 \mathrm{c}$ & $500,59 \mathrm{~b}$ & $5,60 \mathrm{~d}$ \\
Organik Standar & $12,94 \mathrm{c}$ & $2003,00 \mathrm{bc}$ & $653,54 \mathrm{~b}$ & $8,19 \mathrm{c}$ \\
NPK Standar & $73,82 \mathrm{a}$ & $2521,40 \mathrm{a}$ & $2913,36 \mathrm{a}$ & $46,72 \mathrm{a}$ \\
NPK Standar + Organik Standar & $72,84 \mathrm{a}$ & $2279,60 \mathrm{ab}$ & $6069,76 \mathrm{a}$ & $46,10 \mathrm{a}$ \\
3/4 NPK Standar + Organik Standar & $66,39 \mathrm{a}$ & $2388,20 \mathrm{ab}$ & $2258,28 \mathrm{a}$ & $42,02 \mathrm{a}$ \\
1/2 NPK Standar + Organik Standar & $88,72 \mathrm{a}$ & $2529,00 \mathrm{a}$ & $2481,53 \mathrm{a}$ & $56,15 \mathrm{a}$ \\
$1 / 4$ NPK Standar + Organik Standar & $34,30 \mathrm{~b}$ & $2536,50 \mathrm{a}$ & $1835,36 \mathrm{a}$ & $21,71 \mathrm{~b}$ \\
\hline CV (\%) & 5,50 & 10,83 & 5,65 & 6,32 \\
\hline
\end{tabular}

Keterangan: Nilai yang diikuti huruf sama dalam kolom yang sama tidak berbeda signifikan pada Uji Jarak Berganda Duncan $\alpha=5 \%$.

Tabel 7. Bobot segar tajuk, bobot kering akar, bobot kering tajuk dan bobot kering total jagung pada berbagai takaran kombinasi pupuk umur $13 \mathrm{mst}$

\begin{tabular}{|c|c|c|c|c|}
\hline Kombinasi Pupuk & $\begin{array}{l}\text { Bobot Segar } \\
\text { Tajuk (g) }\end{array}$ & $\begin{array}{c}\text { Bobot } \\
\text { Kering } \\
\text { Akar }(\mathrm{g})\end{array}$ & $\begin{array}{c}\text { Bobot } \\
\text { Kering Tajuk } \\
(\mathrm{g})\end{array}$ & $\begin{array}{c}\text { Bobot Kering } \\
\text { Total (Akar + } \\
\text { Tajuk) (g) }\end{array}$ \\
\hline Tanpa Pupuk & $112,61 \mathrm{~d}$ & $2,07 \mathrm{c}$ & $67,99 \mathrm{~d}$ & $70,05 \mathrm{~d}$ \\
\hline Organik Standar & $122,20 d$ & $2,52 \mathrm{c}$ & $71,08 \mathrm{~d}$ & $73,61 \mathrm{~d}$ \\
\hline NPK Standar & 557,68 a & $12,97 \mathrm{a}$ & $297,02 \mathrm{a}$ & $309,99 a$ \\
\hline NPK Standar + Organik Standar & $513,81 a b$ & 12,99 a & $277,51 \mathrm{ab}$ & $290,50 a b$ \\
\hline 3/4 NPK Standar + Organik Standar & $495,48 a b$ & $10,81 \mathrm{a}$ & $267,68 a b$ & $278,50 a b$ \\
\hline $1 / 2$ NPK Standar + Organik Standar & $428,45 \mathrm{bc}$ & $11,62 \mathrm{a}$ & $235,09 \mathrm{~b}$ & $246,70 \mathrm{~b}$ \\
\hline $1 / 14$ NPK Standar + Organik Standar & $333,15 \mathrm{c}$ & $7,84 \mathrm{~b}$ & $181,12 \mathrm{c}$ & $188,96 \mathrm{c}$ \\
\hline CV (\%) & 14,47 & 18,90 & 10,81 & 10,10 \\
\hline
\end{tabular}

Pada perlakuan pemupukan $1 / 4$ NPK standar + organik standar dan $1 / 2$ NPK standar + organik standar asimilat yang terbentuk selama fase reproduktif akan ditranslokasikan untuk pertumbuhan rambut akar, terbukti dari nilai rasio akar tajuk yang tinggi (Tabel 8). Hal ini merupakan bentuk adaptasi untuk mencari sumber nutrisi yang lebih banyak. Sedangkan untuk memenuhi kebutuhan nutrisi selama fase pengisian biji, disuplai dari asimilat yang tersimpan pada daun dan batang karena dilihat dari jumlah dan luas daun keduanya secara nyata lebih rendah (Tabel 5) atau lebih cepat memasuki fase senescence. Rajcan and Tollenaar (1999b) menyebutkan bahwa pengurangan serapan $\mathrm{N}$ selama fase pengisian biji dapat meningkatkan 
mobilisasi $\mathrm{N}$ dari daun dan batang, yang akhirya memicu penuaan daun khususnya daun bagian bawah.

Fase senescence diperlambat dengan peningkatan takaran pupuk NPK. Hasil pengamatan tajuk pada pemupukan $3 / 4$ NPK standar + organik standar, NPK standar + organik standar dan pemupukan NPK standar menunjukkan bahwa pertumbuhan organ vegetatif (Tabel 5) dan organ reproduktif (Tabel 9) optimal tanpa penghambatan pertumbuhan akar (Tabel 4.6 \& 4.7). Dilihat dari analisis pertumbuhan-nya juga menunjukkan hasil yang optimal (Tabel 10). Agren \& Franklin (2003) menyatakan bahwa ketersediaan nutrisi yang meningkat menyebabkan pengoptimalan pertumbuhan tajuk, oleh karenanya asimilat yang terbentuk dapat terdistribusi dengan baik.

Tabel 4.8 Rasio akar dengan tajuk pada berbagai takaran kombinasi pupuk umur 3, 6 dan 13 mst

\begin{tabular}{|c|c|c|c|}
\hline \multirow[t]{2}{*}{ Kombinasi Pupuk } & \multicolumn{3}{|c|}{ Rasio akar tajuk } \\
\hline & $3 \mathrm{mst}$ & $6 \mathrm{mst}$ & $13 \mathrm{mst}$ \\
\hline Tanpa Pupuk & $0,223 \mathrm{c}$ & $0,263 \mathrm{a}$ & $0,030 \mathrm{c}$ \\
\hline Organik Standar & $0,337 a$ & 0,267 a & $0,033 \mathrm{bc}$ \\
\hline NPK Standar & $0,343 a$ & $0,177 \mathrm{~b}$ & $0,043 a b$ \\
\hline NPK Standar + Organik Standar & $0,250 \mathrm{bc}$ & $0,180 \mathrm{~b}$ & $0,050 \mathrm{a}$ \\
\hline 3/4 NPK Standar + Organik Standar & $0,330 \mathrm{ab}$ & $0,210 a b$ & $0,040 \mathrm{abc}$ \\
\hline $1 / 2$ NPK Standar + Organik Standar & $0,240 \mathrm{c}$ & $0,220 a b$ & $0,050 \mathrm{a}$ \\
\hline $1 / 4$ NPK Standar + Organik Standar & $0,233 \mathrm{c}$ & $0,237 \mathrm{ab}$ & $0,046 \mathrm{a}$ \\
\hline
\end{tabular}

Keterangan: Nilai yang diikuti huruf sama dalam kolom yang sama tidak berbeda signifikan pada Uji Jarak Berganda Duncan $\alpha=5 \%$.

Produksi pipilan kering biji jagung per hektar perlakuan $1 / 4$ NPK standar + organik standar dan $1 / 2$ NPK standar + organik standar secara berturut-turut yaitu 2,80 ton/ha dan 4,48 ton/ha (Tabel 9). Hasil kedua perlakuan tersebut secara nyata lebih rendah dibandingkan dengan hasil pipilan kering biji jagung per hektar pada perlakuan NPK standar. Produksi biji yang rendah pada kedua perlakuan tersebut dipengaruhi oleh bobot biji per tongkol, panjang tongkol, diameter tongkol dan bobot 100 biji kedua perlakuan tersebut secara nyata lebih rendah daripada perlakuan NPK standar (Tabel 9). Hal yang sedikit berbeda ditunjukkan pada parameter komponen hasil berupa jumlah baris per tongkol pada kedua perlakuan tersebut tidak berbeda nyata dengan perlakuan NPK standar. Semua perlakuan yang diberi pupuk NPK mempunyai jumlah baris per tongkol yang tidak tidak berbeda nyata yaitu antara 14-16 baris dan hasil ini telah sesuai dengan deskripsi jagung varietas Pioneer 27. Hasil tersebut menunjukkan bahwa pemberian pupuk NPK sangat dibutuhkan tanaman jagung untuk perkembangan biji. Dengan pemberian pupuk NPK, tongkol jagung mampu 
berkembang dan menghasilkan jumlah biji per tongkol sesuai dengan potensi yang dimiliki.

Produksi pipilan kering biji jagung per hektar yang paling tinggi terdapat pada tanaman yang dipupuk dengan NPK standar yaitu sebesar 6,12 ton. Hasil yang sama tinggi ditunjukkan pada perlakuan $3 / 4$ NPK standar + organik standar dengan hasil pipilan kering biji jagung per hektar sebesar 6,09 ton. Hasil yang juga tidak berbeda nyata ditunjukkan pada tanaman yang dipupuk dengan NPK standar + organik standar yaitu 5,56 ton. Ketiga perlakuan tersebut menghasilkan tongkol jagung dengan panjang dan diameter yang sama, serta jumlah baris per tongkol dan bobot biji per tongkol-nya pun tidak berbeda nyata. Akan tetapi bobot 100 biji perlakuan NPK standar secara signifikan lebih berat jika dibandingkan bobot 100 biji perlakuan NPK standar + organik standar dan $3 / 4$ NPK standar + organik standar (Tabel 9). Berdasarkan hal tersebut diduga perlakuan NPK standar menghasilkan biji yang berukuran besar dengan jumlah biji per baris yang lebih sedikit, sedangkan perlakuan NPK standar + organik standar dan $3 / 4$ NPK standar + organik standar menghasilkan biji yang ukurannya lebih kecil namun jumlah biji per baris-nya lebih banyak sehingga bobot biji per tongkol maupun bobot pipilan kering jagung per hektar keduanya sama.

Secara fisiologis, pengurangan takaran NPK sampai 50\% dari takar standar masih mempunyai efisiensi fotosintesis yang tinggi pada umur 6 - 13 mst (Tabel 10), namun penimbunan berat kering oleh tajuk secara signifikan lebih rendah (Tabel 10). Hal ini dikarenakan ILD pada perlakuan $1 / 2$ NPK standar + organik standar secara nyata lebih rendah dibandingkan ILD pada perlakuan NPK standar. Sedangkan tanaman yang dipupuk dengan $3 / 4$ NPK standar + organik standar dan NPK standar + organik standar mempunyai ILD yang tidak berbeda nyata dengan tanaman pada perlakuan NPK standar, oleh karena LPT ketiganya juga tidak berbeda nyata. Pada perlakuan 1/4 dan/atau $1 / 2$ NPK standar + organik standar memiliki luas daun yang nyata lebih rendah dibandingkan dengan luas daun pada perlakuan NPK standar, sehingga ILD-nya secara nyata juga lebih rendah. 
Tabel 9. Panjang tongkol, diameter tongkol, jumlah baris per tongkol, bobot biji per tongkol, bobot 100 biji, bobot pipilan kering jagung per hektar pada berbagai perlakuan kombinasi takaran pupuk

\begin{tabular}{|c|c|c|c|c|c|c|}
\hline Kombinasi Pupuk & $\begin{array}{c}\text { Panjang } \\
\text { Tongkol }(\mathrm{cm})\end{array}$ & $\begin{array}{c}\text { Diameter } \\
\text { Tongkol }(\mathrm{mm})\end{array}$ & $\begin{array}{c}\text { Jumlah Baris } \\
\text { per Tongkol }\end{array}$ & $\begin{array}{c}\text { Bobot Biji per } \\
\text { Tongkol } \\
\text { (g) }\end{array}$ & $\begin{array}{c}\text { Bobot } 100 \text { Biji } \\
(\mathrm{g})\end{array}$ & $\begin{array}{c}\text { Bobot Pipilan } \\
\text { Kering } \\
\text { (ton/ha) }\end{array}$ \\
\hline Tanpa Pupuk & $8,42 d$ & $34,64 d$ & $13,40 \mathrm{c}$ & $34,55 \mathrm{~d}$ & $20,12 d$ & $1,23 d$ \\
\hline Organik Standar & $9,41 \mathrm{~d}$ & $35,82 \mathrm{~d}$ & $14,53 \mathrm{bc}$ & $38,71 \mathrm{~d}$ & $18,99 \mathrm{~d}$ & $1,38 \mathrm{~d}$ \\
\hline NPK Standar & $17,48 \mathrm{a}$ & $52,42 \mathrm{a}$ & $15,67 \mathrm{ab}$ & $171,32 \mathrm{a}$ & $32,00 \mathrm{a}$ & $6,12 a$ \\
\hline NPK Standar + Organik Standar & 16,89 a & 51,20 a & $16,23 \mathrm{a}$ & $155,63 a$ & $27,55 \mathrm{~b}$ & $5,56 a$ \\
\hline $3 / 4$ NPK Standar + Organik Standar & $17,08 \mathrm{a}$ & 53,35 a & $16,69 a$ & $170,42 a$ & $27,46 \mathrm{~b}$ & $6,09 a$ \\
\hline $1 / 2$ NPK Standar + Organik Standar & $15,51 \mathrm{~b}$ & $47,65 \mathrm{~b}$ & $15,60 a b$ & $125,31 \mathrm{~b}$ & $25,75 \mathrm{bc}$ & $4,48 \mathrm{~b}$ \\
\hline $1 / 4$ NPK Standar + Organik Standar & $12,90 \mathrm{c}$ & $42,89 \mathrm{c}$ & $16,40 \mathrm{a}$ & $78,50 \mathrm{c}$ & $22,42 \mathrm{~cd}$ & $2,80 \mathrm{c}$ \\
\hline CV (\%) & 5,13 & 3,32 & 5,23 & 12,27 & 17,14 & 12,28 \\
\hline
\end{tabular}

Keterangan: Nilai yang diikuti huruf sama dalam kolom yang sama tidak berbeda signifikan pada Uji Jarak Berganda Duncan $\alpha=5 \%$ 
Peran mikroba fungsional dalam menstimulasi pertumbuhan dan perkembangan tanaman terlihat dari keragaan tanaman yang lebih tahan terhadap cekaman unsur hara. Pemupukan dengan pupuk organik diperkaya mampu mempertahankan kehijauan daun lebih lama (Tabel 5) dan diikuti dengan penyerapan air oleh akar yang lebih banyak dilihat dari volume dan bobot segarnya yang meningkat (Tabel 4.6).

Tabel 10 Laju asimilasi bersih dan laju pertumbuhan tanaman jagung pada umur 6 - 13 mst dan indeks luas daun jagung pada umur 13 mst pada berbagai perlakuan kombinasi takaran pupuk

\begin{tabular}{lccc}
\hline \multicolumn{1}{c}{ Kombinasi Pupuk } & $\begin{array}{c}\text { Laju Asimilasi Bersih } \\
\left(\mathrm{mg} / \mathrm{cm}^{2} / \mathrm{minggu}\right)\end{array}$ & $\begin{array}{c}\text { Indeks Luas } \\
\text { Daun }\end{array}$ & $\begin{array}{c}\text { Laju } \\
\text { Pertumbuhan } \\
\text { Tanaman } \\
\left(\mathrm{g} / \mathrm{m}^{2} / \mathrm{ming} g \mathrm{~m}\right)\end{array}$ \\
\cline { 2 - 4 } & $6-13 \mathrm{mst}$ & $13 \mathrm{mst}$ & $6-13 \mathrm{mst}$ \\
\hline Tanpa Pupuk & $4,15 \mathrm{c}$ & $0,773 \mathrm{c}$ & $33,46 \mathrm{~d}$ \\
Organik Standar & $4,32 \mathrm{c}$ & $0,810 \mathrm{c}$ & $35,08 \mathrm{~d}$ \\
NPK Standar & $9,65 \mathrm{a}$ & $1,363 \mathrm{a}$ & $145,35 \mathrm{a}$ \\
NPK Standar + Organik Standar & $9,32 \mathrm{a}$ & $1,330 \mathrm{a}$ & $135,61 \mathrm{ab}$ \\
3/4 NPK Standar + Organik Standar & $9,15 \mathrm{a}$ & $1,167 \mathrm{ab}$ & $129,58 \mathrm{ab}$ \\
1/2 NPK Standar + Organik Standar & $8,81 \mathrm{a}$ & $1,087 \mathrm{~b}$ & $114,64 \mathrm{~b}$ \\
1/4 NPK Standar + Organik Standar & $6,96 \mathrm{~b}$ & $1,090 \mathrm{~b}$ & $87,73 \mathrm{c}$ \\
\hline CV (\%) & 9,04 & 10,46 & 13,70 \\
\hline Ke & & &
\end{tabular}

Keterangan: Nilai yang diikuti huruf sama dalam kolom yang sama tidak berbeda signifikan pada Uji Jarak Berganda Duncan $\alpha=5 \%$

Berdasarkan hasil penelitian yang telah dilakukan, dapat disimpulkan bahwa pupuk organik alami diperkaya mikroba fungsional yang digunakan dalam penelitian ini secara teknis/agronomis dinilai efektif mengurangi penggunaan pupuk NPK sebesar $25 \%$. Pengurangan $25 \%$ dari takaran NPK standar yaitu takaran kombinasi pupuk $3 / 4$ NPK standar + organik standar dapat memberikan hasil yang sama baiknya dengan pupuk rekomendasi (NPK standar) dan lebih efektif dibanding takaran kombinasi pupuk NPK standar + organik standar. Meskipun dari perhitungan RAE perlakuan $3 / 4$ NPK standar + organik standar tidak lebih baik dari NPK standar (Tabel 11), namun hal tersebut tidak menjadi satu-satunya kriteria untuk lulus uji secara teknis/agronomis.

Menurut Permentan No.70 tahun 2011, disebutkan bahwa ketentuan lulus uji efektivitas pupuk organik secara teknis ada tiga yaitu apabila: (1) hasil perlakuan pupuk yang diuji secara statistik sama dengan perlakuan standar, atau (2) lebih baik dibanding perlakuan kontrol pada taraf nyata $5 \%$, atau (3) mempunyai $R A E \geq 100 \%$. Berdasarkan hal tersebut, pertumbuhan; analisis pertumbuhan; hasil dan komponen hasil perlakuan $3 / 4$ NPK standar + organik standar secara statistik sama baiknya dengan perlakuan NPK standar dan secara nyata lebih baik dibanding perlakuan 
kontrol. Sehingga 2 ton/ha pupuk organik alami diperkaya mikroba fungsional efektif dikombinasikan dengan $225 \mathrm{~kg} / \mathrm{ha}$ NPK $+187,5 \mathrm{~kg} / \mathrm{ha}$ urea (3/4 NPK standar).

Tabel 11. Nilai RAE (Relative Agronomic Effectiveness) pada berbagai perlakuan kombinasi takaran pupuk

\begin{tabular}{lc}
\hline \multicolumn{1}{c}{ Kombinasi Pupuk } & RAE (\%) \\
\hline Tanpa Pupuk & 0 \\
Organik Standar & 3 \\
NPK Standar & 100 \\
NPK Standar + Organik Standar & 89 \\
3/4 NPK Standar + Organik Standar & 99 \\
$1 / 2$ NPK Standar + Organik Standar & 66 \\
$1 / 4$ NPK Standar + Organik Standar & 32 \\
\hline
\end{tabular}

\section{KESIMPULAN}

1. Pertumbuhan dan hasil pipilan kering biji jagung optimal yaitu 6,12 ton/ha dicapai oleh perlakuan $300 \mathrm{~kg} / \mathrm{ha}$ NPK $+250 \mathrm{~kg} / \mathrm{ha}$ urea (NPK standar).

2. Takaran kombinasi pupuk $225 \mathrm{~kg} / \mathrm{ha}$ NPK $+187,5 \mathrm{~kg} / \mathrm{ha}$ urea +2 ton/ha pupuk organik alami diperkaya mikroba fungsional ( $3 / 4$ NPK standar + organik standar) memberikan pertumbuhan dan hasil jagung $(6,09$ ton/ha) yang sama baiknya dengan takaran NPK standar.

3. Pupuk organik alami diperkaya mikroba fungsional sebanyak 2 ton/ha yang dikombinasikan dengan $3 / 4$ NPK standar efektif meningkatkan pertumbuhan dan hasil jagung dengan nilai RAE mendekati $100 \%$.

\section{DAFTAR PUSTAKA}

Agren, G.I. and O. Franklin, 2003. Root: shoot ratios, optimization and nitrogen productivity. Annals of Botany, 92: $795-800$.

Bonifas, K.D., D.T. Walters, K.G. Cassman and J.L. Lindquist, 2005. Nitrogen supply affects root: shoot ratio in corn and velvetleaf (Abutilon theophrasti). Weed Science, 53: $670-675$.

BPS. 2016a. Pdb triwulanan atas dasar harga konstan 2010 menurut lapangan usaha (miliar rupiah), 2014-2016. https://www.bps.go.id/link TableDinamis/view/id/827. Diakses 27 Juli 2016.

BPS. 2016c. Produksi jagung menurut provinsi (ton), 1993-2015. https://www.bps.go. id/linkTableDinamis/view/id/868. Diakses pada 27 Juli 2016.

Dupuis, I. and C. Dumas, 1990. Influence of temperature stress on in vitro fertilization and heat shock protein synthesis in maize (Zea mays L.) reproductive tissues. Plant Physiol, 94: 665 - 670.

Gerpacio, R.V. and P.L. Pingali. 2007. Tropical and subtropical maize in Asia: production systems, constraints and research priorities. CIMMYT, Mexico. 
Heggenstaller, A., 2016. Crop insights: managing soil ph for crop production. https://www.pioneer.com/home/site/us/agronomy/library/managing-soilpH/. Diakses 15 Juni 2016.

Kasno, A. dan T. Rostaman, 2013. Serapan hara dan peningkatan produktivitas jagung dengan aplikasi pupuk npk majemuk. Penelitian Pertanian Tanaman Pangan, 32: 179-186.

Kementan, 2015. Rencana strategis kementerian pertanian tahun $2015-2019$. Kementerian Pertanian, Jakarta.

Kresnatita, S., Koesriharti dan M. Santoso, 2013. Pengaruh rabuk organik terhadap pertumbuhan dan hasil tanaman jagung manis. Indonesian Green Technology Journal, 2: 8 - 17.

Litbang Pertanian, 2012. Peraturan menteri pertanian no.70/permentan/sr.140/10/2011 tentang pupuk organik, pupuk hayati, dan pembenah tanah. Jakarta.

Plessis, J.D., 2003. Maize production. arc-grain crop institute. Departemen Agriculture Republic of South Africa, South Africa.

Pusdatin Kementan, 2015. Outlook komoditas pertanian subsektor tanaman pangan jagung. Pusat Data dan Sistem Informasi Pertanian, Kementerian Pertanian, Jakarta.

Rajcan, I. and M. Tollenaar, 1999a. Source: sink ratio and leaf senescence in maize: I. dry matter accumulation and partitioning during grain filling. Field Crop Research, 60: $245-$ 253.

Rajcan, I. and M. Tollenaar., 1999b. Source: sink ratio and leaf senescence in maize: II. nitrogen metabolism during grain filling. Field Crop Research, 60: $255-265$.

Savci, S., 2012a. Investigation of effect of chemical fertilizers on environment. APCBEE Procedia, 1: $287-292$.

Schlenker, W. and M.J. Roberts, 2009. Nonlinear temperature effects indicate severe damage to U.S. crop yields under climate change. Proc. Natl. Acad. Sci., 106: 15594 - 15598.

Schoper, J.B., R.J. Lambert, B.L. Vasilas and M.E. Westgate, 1987. Plant factors controlling seed set in maize. Plant Physiol, 83: 121 - 125.

The, C., H. Calba, C. Zonkeng, E.L.M. Ngonkeu, V.O. Adetimirin, H.A. Mafouasson, S.S. Meka and W.J. Horst, 2006. Response of maize grain yield to changes in acid soil characteristics after soil amendments. Plant and Soil, 284: $45-57$.

Tollenaar, M. and L.M. Dwyer, 1999. Physiology of maize. In: D. L. Smith and C. Hame $1^{\text {st }}$ Eds. Physiological control of growth and yield in field crops. Springer-Verlag, Berlin. p: $169-204$. 